\title{
Pengaruh berbagai dosis nitrogen dan waktu pemberian pupuk organik cair terhadap pertumbuhan dan produksi tanaman terung hijau (Solanum melongena L.)
}

\section{(Effect of different level of nitrogen and time of liquid organic fertilizer application on the growth and production of green eggplant (Solanum melongena L.))}

\author{
D. Purba, D.W. Widjajanto, dan E.D. Purbajanti \\ Department of Agriculture, Faculty of Animal and Agricultural Sciences, Diponegoro University \\ Tembalang Campus, Semarang 50275 - Indonesia \\ Corresponding E-mail:purbadedi006@gmail.com
}

\begin{abstract}
Experiment was aimed to evaluate the effect of different doses of nitrogen and time of application of liquid organic fertilizer (LOF) and the interaction of the two treatments on growth and production of green eggplant. A completely randomized design arranged as $4 \times 3$ factorial pattern was used throughout the experiment. Each experimental unit was replicated three times. The first factor consisted of different doses of LOF namely D0 : no added-LOF, D1 : $25 \mathrm{~kg} \mathrm{~N} / \mathrm{ha}$, D2 : $50 \mathrm{~kg} \mathrm{~N} / \mathrm{ha}$, D3 : $75 \mathrm{~kg} \mathrm{~N} / \mathrm{ha}$, respectively equivalent to $800,1600,2400 \mathrm{ml} \mathrm{LOF} /$ plant. The second factor was the application time of LOF consisted of M1, M2 and M3 consecutively for 7, 28 days after planting (DAP) and at flowering stage. The parameters observed included the number of leaves, plant chlorophyll, number and weight of fresh fruit. Collected data were analyzed by using ANOVA and the Duncan Multiple Range Test (DMRT) was used for further analysis. The results showed that there was a significant interaction effect of different level of LOF treatment and time of LOF application especially on fresh fruit weights. The dosage of LOF $1600 \mathrm{ml} / \mathrm{plant}$ increased the number of fruit. The combination treatment of $2400 \mathrm{ml} / \mathrm{plant}$ and 7 DAP increased the physical quality of the green eggplant plant.
\end{abstract}

Keywords: green eggplant, liquid organic fertilizer, nitrogen, time of LOF application

\begin{abstract}
ABSTRAK
Percobaan bertujuan untuk mengevaluasi efek dari berbagai dosis nitrogen dan waktu penerapan pupuk organik cair (POC) dan interaksi dari dua perlakuan pada pertumbuhan dan produksi terong hijau. Desain acak lengkap disusun sebagai pola faktorial $4 \times 3$ digunakan di seluruh percobaan. Setiap unit percobaan diulang tiga kali. Faktor pertama terdiri dari berbagai dosis POC yaitu D0: tidak ada penambahan POC, D1: $25 \mathrm{~kg} \mathrm{~N} / \mathrm{ha}, \mathrm{D} 2: 50 \mathrm{~kg} \mathrm{~N} / \mathrm{ha}, \mathrm{D} 3: 75 \mathrm{~kg} \mathrm{~N} / \mathrm{ha}$, masing-masing setara dengan 800, 1600, $2400 \mathrm{ml}$ POC/tanaman. Faktor kedua adalah waktu aplikasi POC terdiri dari M1, M2 dan M3 berturut-turut selama 7, 28 hari setelah tanam (HST) dan pada saat berbunga. Parameter yang diamati meliputi jumlah daun, klorofil daun tanaman, jumlah dan bobot buah segar. Data yang dikumpulkan dianalisis dengan menggunakan ANOVA dan Duncan Multiple Range Test (DMRT) digunakan untuk analisis lebih lanjut. Hasil penelitian menunjukkan bahwa ada pengaruh interaksi yang signifikan dari tingkat perlakuan POC yang berbeda dan waktu aplikasi POC terutama pada bobot buah segar. Dosis POC $1600 \mathrm{ml} /$ tanaman meningkatkan jumlah buah. Perlakuan kombinasi $2400 \mathrm{ml} /$ tanaman dan $7 \mathrm{HST}$ meningkatkan kualitas fisik tanaman terung hijau.

Kata kunci: terung hijau, pupuk organik cair, nitrogen, waktu aplikasi POC
\end{abstract}




\section{PENDAHULUAN}

Terung merupakan komoditas sayuran bergizi tinggi, mengandung 26 kalori, $1 \mathrm{~g}$ protein, 0,2 g karbohidrat arang, $25 \mathrm{IU}$ vitamin A, 0,04 g vitamin $\mathrm{B}$ dan $5 \mathrm{~g}$ vitamin $\mathrm{C}$ dalam $100 \mathrm{~g}$ bahan mentah (Jumini dan Ainun, 2009). Oleh karena itu terung sangat baik untuk dikonsumsi dalam menjaga kebugaran dan kesehatan tubuh.

Permintaan pasar terhadap terung di Indonesia setiap tahunnya meningkat, dikarenakan jumlah penduduk yang meningkat hingga 254 juta jiwa (BPS, 2015). Tingginya permintaan terung pada tahun 2014 sekitar 740.000 ton/ha tidak diimbangi dengan produktivitas terung di Indonesia (BPS, 2015). Produksi terung di Indonesia pada tahun 2014 sekitar 557.040 ton/ha mengalami kenaikan dibandingkan dengan produksi tahun 2013 sekitar 545.646 ton/ha (Kementrian Pertanian Republik Indonesia, 2015).

Produktivitas perlu ditingkatkan lagi mulai dari perbaikan teknis budidaya terung hingga perlakuan pasca panen. Salah satu yang perlu diperhatikan dalam budidaya terung adalah ketersediaan unsur hara yang cukup untuk mendukung pertumbuhan dan produksi terung baik kualitas dan kuantitas Ketersediaan unsur hara tanah atau media tanam sangat bervariasi. Oleh karena itu, bagi tanah atau media tanam yang miskin hara perlu ditingkatkan kesuburannya melalui pemupukan.

Pemupukan dapat dilakukan untuk mencukupi kebutuhan hara tanaman, dan dapat diaplikasikan baik dalam bentuk pupuk anorganik maupun organik. Penggunaan pupuk organik merupakan pilihan dalam usaha pertanian berkelanjutan, dikarenakan pupuk organik tidak hanya mensuplai unsur hara kedalam tanah tetapi terbukti mampu memperbaiki sifat fisik, kimia dan biologi tanah. Pupuk organik cair dapat bersumber dari urin ternak seperti sapi, kambing, domba dan lainnya. Urin sapi merupakan merupakan salah satu sumber limbah organik berpotensi untuk dijadikan pupuk organik cair (POC), dikarenakan urin sapi mengandung unsur hara lengkap seperti $1,4-2,2 \% \mathrm{~N}, 0,6-0,7 \% \mathrm{P}$ dan 1,6-2,1\%K (Rizqiani dkk., 2007).

Pembuatan POC berbahan dasar urin sapi memerlukan proses fermentasi dengan menggunakan mikroorganisme lokal (MoL).
Larutan MoL mengandung mikroorganisme yang berfungsi sebagai dekomposer, pupuk hayati dan pestisida organik. Dalam pembuatan pupuk organik cair (POC) sering kali digunakan $\mathrm{MoL}$ bersumber bonggol pisang untuk mempercepat pematangan. Pembuatan MoL membutuhkan waktu 3 Minggu dimana bahan baku MoL sudah hancur dan terurai dengan sempurna (Juanda dkk., 2011).

Tujuan penelitian adalah mengevaluasi efek dari berbagai dosis nitrogen dan waktu penerapan pupuk organik cair (POC) dan interaksi dari dua perlakuan pada pertumbuhan dan produksi terung hijau.

\section{MATERI DAN METODE}

Penelitian telah dilaksanakan di greenhouse Dinas Pertanian Kota Semarang,berlokasi di Kecamatan Gunungpati, Kota Semarang. Lokasi Penelitian terletak pada koordinat $7^{\circ} 3$ '57' LS $7^{\circ} 30^{\prime}$ LS dan $110^{\circ} 14^{\prime} 54,75^{\prime \prime}$ BT-110 $399^{\prime} 3$ " BT, pada ketinggian tempat $348 \mathrm{mdpl}$, dengan ratarata suhu harian berkisar antara $19^{\circ} \mathrm{C}-30^{\circ} \mathrm{C}$ dan rata-rata curah hujan bulanan mencapai 284,71 $\mathrm{mm} /$ bulan (BMKG, 2012). Penelitian laboratorium dilakukan di laboratorium Ekologi dan Produksi Tanaman, Fakultas Peternakan dan Pertanian Universitas Diponegoro. Penelitian dilaksanakan selama 4 bulan, mulai bulan Februari sampai Juli 2018. Materi yang digunakan dalam penelitian yaitu bibit terung hibrida F1 liberto, media tanam, POC, MoL berbahan dasar buah dan sayur. Alat yang digunakan adalah corong, jerigen, pot diameter $35 \mathrm{~cm}$, cangkul, timbangan analitik, meteran, higrometer, tali rafia, ajir (turus), plastik dan kertas label, $\mathrm{pH}$ meter, pisau, alat tulis dan kamera

\section{Metode Penelitian}

Kegiatan penelitian diawali dengan pembuatan MoL dan dilanjutkan dengan pembuatan POC yang diperam selama 18 hari dalam suhu ruang. Penyemaian benih terung F1 liberto dilakukan dengan menyiapkan media untuk persemaian benih. Benih yang telah dipersiapkan direndam dahulu dengan tujuan menyeleksi benih yang baik dan untuk mempercepat perkecambahan. Menjaga kelembaban tempat persemaian dengan penyemprotan air. Penyemaian 
benih dilakukan selama 14 hari. Bibit terung F1 liberto yang telah berumur 14 hari atau sudah siap pindah tanam, dipindahkan ke pot yang telah disiapkan. Bibit terung F1 liberto dimasukan kelubang tanam sedalam $\pm 2-5 \mathrm{~cm}$ sebanyak satu bibit per lubang tanam. Pemeliharaan tanaman terung dilakukan dengan menyiramkan air setiap hari pada pagi dan sore hari. Penyiangan dilakukan dengan membersihkan gulma yang ada disekitar tanaman. Pemanenan dilakukan setelah tanaman berumur 55-60 HST dan dilakukan satu lebih lanjut.

\section{HASIL DAN PEMBAHASAN}

\section{Jumlah daun}

Hasil analisis ragam menunjukkan bahwa tidak terdapat pengaruh nyata perlakuan dosis POC dan waktu pemupukan serta interaksi kedua perlakuan terhadap jumlah daun tanaman terung hijau. Jumlah daun pada perlakuan dosis POC dan waktu pemupukan disajikan pada Tabel 1.

Tabel 1. Jumlah Daun pada Perlakuan Dosis POC dan Waktu Pemupukan

\begin{tabular}{|c|c|c|c|c|}
\hline \multirow{2}{*}{$\begin{array}{c}\text { Dosis POC } \\
(\mathrm{kg} \mathrm{N} / \mathrm{ha})\end{array}$} & \multicolumn{3}{|c|}{ Waktu Pemupukan } & \multirow{2}{*}{ Rerata } \\
\hline & $\mathrm{M}_{1}(7 \mathrm{HST})$ & $\mathrm{M}_{2}(28 \mathrm{HST})$ & $\mathrm{M}_{3}$ (Saat Berbunga) & \\
\hline \multicolumn{5}{|c|}{---------------------(helai)----------------------- } \\
\hline $\mathrm{D}_{0}(0)$ & 7,67 & 6,33 & 6,33 & 6,77 \\
\hline$D_{1}(25)$ & 7,00 & 6,00 & 8,00 & 7,00 \\
\hline $\mathrm{D}_{2}(50)$ & 6,67 & 6,33 & 8,67 & 7,22 \\
\hline$D_{3}(75)$ & 10,00 & 7,33 & 6,00 & 7,78 \\
\hline Rerata & 7,84 & 6,50 & 8,81 & 7,71 \\
\hline
\end{tabular}

kali pemanenan. Buah dipanen pada pagi dan sore hari. Kriteria tanaman siap untuk dipanen adalah masak fisiologis, panjang buah mencapai 25-30 $\mathrm{cm}$.

Parameter yang diamati yaitu jumlah daun, klorofil daun tanaman, jumlah buah, dan bobot buah segar.

\section{Rancangan Percobaan dan Analisis Data}

Rancangan yang digunakan adalah Rancangan Acak Lengkap (RAL) pola faktorial $4 \times 3$. Setiap unit percobaan diulang diulang tiga kali. Faktor pertama terdiri dari berbagai dosis POC yaitu D0: tidak ada penambahan POC, D1: $25 \mathrm{~kg} \mathrm{~N} / \mathrm{ha}$, D2: $50 \mathrm{~kg} \mathrm{~N} / \mathrm{ha}, \mathrm{D} 3: 75 \mathrm{~kg} \mathrm{~N} / \mathrm{ha}$, masing-masing setara dengan $800,1600,2400 \mathrm{ml}$ POC/tanaman. Faktor kedua adalah waktu aplikasi POC, M1, M2 dan M3 berturut-turut selama 7, 28 hari setelah tanam (HST) dan pada saat berbunga. Parameter yang diamati meliputi jumlah daun, klorofil tanaman, jumlah dan berat buah segar. Data yang dikumpulkan dianalisis dengan menggunakan ANOVA dan Duncan Multiple Range Test (DMRT) digunakan untuk analisis
Perlakuan dosis POC dan waktu pemupukan tidak mempengaruhi jumlah daun. Penambahan POC tidak mempengaruhi jumlah daun karena diduga ketersediaan $\mathrm{N}$ yang bersumber dari POC berjalan lambat dikarenakan proses mineralisasi POC berlangsung lambat. Pupuk organik cair yang ditambahkan belum terdekomposisi dengan baik oleh mikroorganisme dalam tanah. Nilai ratio $\mathrm{C} / \mathrm{N}$ tanah yang digunakan dalam penelitian yaitu 27,84. Kecepatan dekomposisi bahan organik dipengaruhi oleh besarnya rasio $\mathrm{C} / \mathrm{N}$. Tinggi rendahnya nilai rasio $\mathrm{C} / \mathrm{N}$ dekomposisi. Nilai rasio $\mathrm{C} / \mathrm{N}$ yang tinggi menandakan terdapat bahan tahan lapuk yang banyak (selulosa, lemak dan lilin), semakin kecil nilai rasio $\mathrm{C} / \mathrm{N}$ menunjukkan bahwa bahan organik mudah untuk terdekomposisi. Nilai rasio $\mathrm{C} / \mathrm{N}$ yang baik antara 20-30 dan stabil pada rasio C/N 15 (Djuarnani dkk, 2004). Nilai rasio C/ $\mathrm{N}$ rendah mengakibatkan proses dekomposisi berlangsung cepat dan sebaliknya (Krismawati dan Asni, 2011)

\section{Klorofil Daun Tanaman}

Hasil analisis ragam menunjukkan bahwa 
Tabel 2. Klorofil Daun Tanaman pada Perlakuan Dosis POC dan Waktu Pemupukan

\begin{tabular}{lcccc}
\hline \hline \multirow{2}{*}{$\begin{array}{c}\text { Dosis POC } \\
(\mathrm{kg} \mathrm{N} / \mathrm{ha})\end{array}$} & \multicolumn{3}{c}{ Waktu Pemupukan } & \multirow{2}{*}{ Rerata } \\
\cline { 2 - 3 } & $\mathrm{M}_{1}(7 \mathrm{HST})$ & $\mathrm{M}_{2}(28 \mathrm{HST})$ & $\mathrm{M}_{3}$ (Saat Berbunga) & \\
& $-------------------(\mathrm{mg} / \mathrm{g})------------------$ & \\
$\mathrm{D}_{0}(0)$ & 0,682 & 0,654 & 0,865 & 0,734 \\
$\mathrm{D}_{1}(25)$ & 0,458 & 0,531 & 0,486 & 0,491 \\
$\mathrm{D}_{2}(50)$ & 0,667 & 0,807 & 0,616 & 0,700 \\
$\mathrm{D}_{3}(75)$ & 0,559 & 0,629 & 0,472 & 0,554 \\
Rerata & 0,594 & 0,655 & 0,610 & 0,620 \\
\hline
\end{tabular}

tidak terdapat pengaruh nyata perlakuan dosis POC dan waktu pemupukan serta interaksi kedua perlakuan terhadap klorofil daun tanaman terung hijau. Klorofil daun tanaman pada perlakuan dosis POC dan waktu pemupukan disajikan pada Tabel 2.

Perlakuan dosis POC dan waktu pemupukan tidak mempengaruhi klorofil daun tanaman. Penambahan POC tidak berpengaruh pada klorofil daun tanaman, diduga karena pengaruh sifat genetis lebih dominan dibanding aplikasi POC. Sesuai dengan Wijaya dkk. (2015) yang menyatakan bahwa klorofil suatu tanaman tidak hanya ditentukan oleh hara yang cukup dan seimbang tetapi juga dipengaruhi sifat genetis serta memerlukan lingkungan yang baik termasuk sifat fisik dan biologis tanah sebagai faktor pendukung. Disamping itu, klorofil suatu tanaman dipengaruhi oleh umur tanaman, umur daun, morfologi daun dan faktor genetik. Semakin meningkat umur tanaman akan memacu tanaman untuk menyerap unsur hara, air dan cahaya untuk pertumbuhannya Setiari dan Nurcahayati (2009)

\section{Jumlah Buah}

Hasil analisis ragam menunjukkan bahwa tidak terdapat interaksi antara dosis POC dan waktu pemupukan terhadap jumlah buah tanaman terung hijau. Terdapat pengaruh nyata perlakuan dosis POC terhadap jumlah buah terung hijau, tetapi tidak terdapat pengaruh nyata perlakuan waktu pemupukan terhadap jumlah buah terung hijau. Jumlah buah pada perlakuan dosis POC dan waktu pemupukan disajikan pada Tabel 3.

Hasil uji jarak berganda Duncan menunjukkan bahwa dosis POC nyata meningkatkan jumlah buah. Dosis POC $50 \mathrm{~kg}$ $\mathrm{N} / \mathrm{ha}$ nyata lebih tinggi dibanding jumlah buah pada kontrol dan dosis POC $25 \mathrm{~kg} \mathrm{~N} / \mathrm{ha}$ aman tetapi tidak berbeda terhadap dosis POC $75 \mathrm{~kg}$ $\mathrm{N} / \mathrm{ha}$. Hal ini diduga pada dosis POC rendah suplai unsur hara utamanya nitrogen tidak dapat memenuhi kebutuhan tanaman sehingga pertumbuhan vegetatif tanaman terganggu dan mengakibatkan pertumbuhan reproduktif terganggu dan dicerminkan dari rendahnya

Tabel 3. Jumlah Buah pada Perlakuan Dosis POC dan Waktu Pemupukan

\begin{tabular}{|c|c|c|c|c|}
\hline \multirow{2}{*}{$\begin{array}{c}\text { Dosis POC (kg } \\
\mathrm{N} / \mathrm{ha})\end{array}$} & \multicolumn{3}{|c|}{ Waktu Pemupukan } & \multirow{2}{*}{ Rerata } \\
\hline & $\mathrm{M}_{1}(7 \mathrm{HST})$ & $\mathrm{M}_{2}(28 \mathrm{HST})$ & $\mathrm{M}_{3}$ (Saat Berbunga) & \\
\hline & - & --(buah)-------- & - & \\
\hline $\mathrm{D}_{0}(0)$ & 1,67 & 1,33 & 1,67 & $1,56^{\mathrm{c}}$ \\
\hline$D_{1}(25)$ & 2,33 & 2,33 & 2,67 & $2,44^{\mathrm{b}}$ \\
\hline $\mathrm{D}_{2}(50)$ & 3,00 & 2,33 & 3,00 & $2,78^{\mathrm{a}}$ \\
\hline $\mathrm{D}_{3}(75)$ & 2,33 & 2,67 & 3,00 & $2,67^{\mathrm{a}}$ \\
\hline Rerata & 2,33 & 2,17 & 2,59 & 2,36 \\
\hline
\end{tabular}


produksi buah. Sementara itu pada dosis POC tinggi sampai $75 \mathrm{~kg} \mathrm{~N} / \mathrm{ha}$ kebutuhan nutrisi tanaman terpenuhi walaupun produksi buah tidak menunjukkan perbedaan nyata terhadap dosis pupuk optimal $50 \mathrm{~kg} \mathrm{~N} / \mathrm{ha}$. Suplai unsur hara yang tinggi pada dosis POC $75 \mathrm{~kg} \mathrm{~N} / \mathrm{ha}$ tidak akan memiliki fungsi positif terhadap pertumbuhan tanaman dikarenakan kebutuhan nutrisi tanaman telah tercukupi. Unsur hara yang ekses tidak dapat dimanfaatkan tanaman dikarenakan kebutuhan tanaman akan nutrisi telah terpenuhi dengan baik. Hal ini sesuai dengan pendapat Rizqiani dkk. (2007) mengatakan bahwa semakin tinggi konsentrasi pemupukan POC maka kandungan unsur hara tersedia didalam tanah melebihi kebutuhan tanaman sehingga tidak memiliki pengaruh nyata terhadap serapan hara oleh tanaman yang berakibat terhadap produksi tanaman. Aplikasi POC dengan dosis $10 \mathrm{l} / \mathrm{ha}$ memberikan produksi pada tanaman buncis yaitu sebesar 8,07 ton/ha sedangkan dosis $20 \mathrm{l} / \mathrm{ha}$ memberikan produksi 7,88 ton/ha. Semakin tinggi konsentrasi aplikasi POC, kandungan unsur hara tersedia semakin tinggi dan tidak sesuai dengan batas kemampuan tanaman (Luthfyrakhman dan Susila, 2013).

Waktu pemupukan tidak berpengaruh nyata terhadap jumlah buah tanaman terung hijau. Hal ini diduga pada produksi tanaman, jumlah buah berkaitan dengan jumlah bunga yang dihasilkan tanaman. Proses pembungaan untuk menjadi bakal buah memerlukan waktu dua minggu dan untuk menjadi buah masak memerlukan waktu dua minggu (Lakitan, 2011). Bunga yang terbentuk tidak semua dapat mengalami pembuahan dan buah yang terbentuk tidak semua tumbuh menjadi buah masak. Hal ini sesuai dengan Jumin (2006) yang menyatakan bahwa pembetukan dan pengisian buah sangat dipengaruhi ketersediaan unsur hara untuk proses fotosintesis yang menghasilkan karbohidrat, lemak, protein, mineral dan vitamin yang ditranslokasikan kebagian penyimpanan seperti buah. Proses pembungaan dan pembuahan pada tanaman juga dipengaruhi oleh faktor luar yaitu temperatur, suhu, panjang pendeknya hari dan ketinggian tempat (Marviani dan Utami, 2014).

\section{Bobot Buah Segar}

Hasil analisis ragam menunjukkan adanya interaksi perlakuan dosis POC dan waktu pemupukan terhadap bobot buah segar. Terdapat pengaruh nyata perlakuan dosis POC terhadap bobot buah segar, tetapi tidak terdapat pengaruh nyata waktu pemupukan terhadap bobot buah segar. Bobot buah segar pada perlakuan dosis POC dan waktu pemupukan yang berbeda disajikan pada Tabel 4.

Hasil uji jarak berganda Duncan menunjukkan bahwa terdapat interaksi perlakuan dosis POC dan waktu pemupukan terhadap bobot buah segar. Dosis POC pada waktu pemupukan 7 HST dan 28 HST meningkatkan bobot buah segar. Dosis POC $50 \mathrm{~kg} \mathrm{~N} / \mathrm{ha}$ pada waktu berbunga mampu meningkatkan bobot buah segar terung hijau, sementara dosis POC $75 \mathrm{~kg}$ N/ha pada waktu berbunga menurunkan bobot buah segar terung hijau. Bobot buah segar tertinggi pada waktu pemupukan 7 HST pada dosis POC $25 \mathrm{~kg}$ $\mathrm{N} /$ ha yang tidak berbeda nyata dengan dosis POC $75 \mathrm{~kg} \mathrm{~N} / \mathrm{ha}$ masing - masing sebesar 174,39 g dan 198,13 g. Bobot buah segar tertinggi pada waktu pemupukan 28 HST pada dosis $75 \mathrm{~kg} \mathrm{~N} / \mathrm{ha}$ sebesar 181,04 g. Bobot buah segar tertinggi pada

Tabel 4. Bobot Buah Segar pada Perlakuan Dosis POC dan Waktu Pemupukan yang Berbeda

\begin{tabular}{|c|c|c|c|c|}
\hline \multirow{2}{*}{$\begin{array}{c}\text { Dosis POC (kg } \\
\mathrm{N} / \mathrm{ha})\end{array}$} & \multicolumn{3}{|c|}{ Waktu Pemupukan } & \multirow{2}{*}{ Rerata } \\
\hline & $\mathrm{M}_{1}(7 \mathrm{HST})$ & $\mathrm{M}_{2}(28 \mathrm{HST})$ & $\mathrm{M}_{3}$ (Saat Berbunga) & \\
\hline \multicolumn{5}{|c|}{ 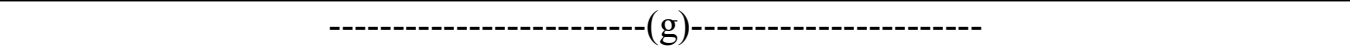 } \\
\hline $\mathrm{D}_{0}(0)$ & $66,12^{\text {ef }}$ & $78,99^{\mathrm{e}}$ & $93,08^{\mathrm{e}}$ & $79,40^{\mathrm{c}}$ \\
\hline $\mathrm{D}_{1}(25)$ & $174,39^{\mathrm{b}}$ & $127,76^{\mathrm{d}}$ & $140,25^{\mathrm{c}}$ & $147,47^{\mathrm{b}}$ \\
\hline $\mathrm{D}_{2}(50)$ & $134,85^{\mathrm{c}}$ & $126,10^{\mathrm{d}}$ & $145,18^{\mathrm{b}}$ & $136,37^{\mathrm{b}}$ \\
\hline $\mathrm{D}_{3}(75)$ & $198,13^{\mathrm{a}}$ & $181,04^{\mathrm{a}}$ & $122,60^{\mathrm{d}}$ & $167,26^{\mathrm{a}}$ \\
\hline Rerata & 143,37 & 128,47 & 125,28 & 174,43 \\
\hline
\end{tabular}


waktu saat berbunga pada dosis $50 \mathrm{~kg} \mathrm{~N} / \mathrm{ha}$ sebesar 145,18 g. Tingginya bobot buah segar pada tanaman terung hijau diduga unsur hara yang diberikan dapat memenuhi kebutuhan hara selama fase generatif. Unsur hara merupakan faktor yang mempengaruhi bobot buah segar, dikarenakan dalam pembentukan buah, tanaman memerlukan unsur hara dalam jumlah besar antara lain posfor (P) dan kalium (K). Hal ini sesuai dengan pendapat Sutedjo (2002) unsur hara posfor (P) dapat merangsang proses pembentukan bunga, buah dan biji serta mempercepat pembentukan dan pematangan buah terung, sedangkan kalium (K) menjegah terjadinya kerontokan bunga tanaman. Pertumbuhan dan hasil tanaman terung akan lebih baik apabila semua unsur hara yang dibutuhkan oleh tanaman berada dalam keadaan tersedia dan cukup (Marliah dkk, 2012).

\section{KESIMPULAN}

Hasil penelitian dapat disimpulkan bahwa dosis POC $50 \mathrm{~kg} \mathrm{~N} /$ ha dapat meningkatkan jumlah buah. Dosis POC $75 \mathrm{~kg} \mathrm{~N} / \mathrm{ha}$ dengan waktu pemupukan 7 HST, 28 HST dan saat berbunga meningkatkan kualitas fisik terung hijau.

\section{DAFTAR PUSTAKA}

BMKG. 2012. Curah Hujan Rata-rata Bulanan Kota Semarang. Badan Metereologi Klimatologi dan Geofisika. Semarang

BPS. 2015. Perkiraan Permintaan Buah di Indonesia Sampai dengan tahun 2015. Badan Pusat Statistika. Jakarta.

Djuarnani, N., Kristian. dan B.S. Setiawan. 2004. Cara Cepat Membuat Kompos. Agromedia. Jakarta.

Juanda., Irfan., dan Nurdiana. 2011. Pengaruh metode dan lama fermentasi terhadap mutu MoL (Mikroorganisme Lokal). J. Floratek. $6: 140-143$.

Jumin, M. S. 2006. Dasar-dasar Agronomi. Raja Grafindo Perkasa. Jakarta

Jumini., dan M. Ainun. 2009. Pertumbuhan dan hasil tanaman terung akibat pemberian pupuk daun gandasil $\mathrm{d}$ dan zat pengatur tumbuh. J. Floratek. 4: 73-80.

Kementrian Pertanian Republik Indonesia. 2015. Statistik Produksi Hortikultura tahun 2014. Direktorat Jenderal Hortikultura Kementerian pertanian. Jakarta

Krismawati, A. dan R. Asnita. 2011. Pupuk organik dari limbah organik sampah rumah tangga. Badan Litbang Pertanian. Edisi 3-9 Agustus 2011 No. 3417 Tahun XII.

Lakitan, B. 2011. Dasar - dasar Fisiologi Tumbuhan. Raja Grafindo Persada. Jakarta.

Luthfyrakhman, H. dan A.D. Susila. 2013. Optimasi dosis pupuk anorganik dan pupuk kandang ayam pada budidaya tomat hibrida. Buletin Agrohorti. 1(1): 119-126.

Marliah, A., M. Hayati. dan M. Indra. 2012. Pemanfaatan pupuk organik cair terhadap pertumbuhan dan hasil beberapa varietas tomat (Lycopersicum Esculentum L.). J. Agrivita. 16 (3): 122 -128

Marviani, D.D. dan L.B. Utami. 2014. Respon pertumbuhan tanaman terung (Solanum melongena L.) terhadap pemberian kompos berbahan dasar tongkol jagung dan kotoran kambing. Jupemasi Pbio. 1 (1) : 161-166.

Rizqiani, N.F., E. Ambarwati. dan N.W. Yuwono. 2007. Pengaruh dosis dan frekuensi pemberian pupuk organik cair terhadap pertumbuhan dan hasil buncis (Phaseolus vulgaris L.) dataran rendah. J. Ilmu Tanah dan Lingkungan. 7 (1): 43-53.

Setiari, N., dan Y. Nurcahayati. 2009. Eksplorasi kandungan klorofil pada beberapa sayuran hijau sebagai alternatif bahan dasar food supplement. BIOMA. 11 (1): 6-10

Sutedjo, M. M dan A. G Kartasapoetra. 2002. Pengantar Ilmu Tanah. Bina Aksara. Jakarta 
J. Agro Complex 3(3):159-165, October 2019

DOI: https://doi.org/10.14710/joac.3.3.159-165

Wijaya, A. S., M. N. Sangadji. dan Muhardi. 2015. Produksi dan kualitas produksi buah tomat yang diberi berbagai konsentrasi pupuk http://ejournal2.undip.ac.id/index.php/joac ISSN 2597-4386

organik cair. Jurnal Agrotekbis. 3 (6) : 689696. 